Uniwersytet im. Adama Mickiewicza, Poznań

\title{
Wolność wypowiedzi i prawo do krytyki a lojalność wobec czlonków samorządu zawodowego - rozważania na tle orzeczenia TK w sprawie art. 53 Kodeksu Etyki Lekarskiej
}

Drzedmiotem niniejszego opracowania jest analiza regulacji przyjętych przez organy samorządu zawodowego lekarzy, wprowadzających zasadę lojalności zawodowej. Pretekstem do podjęcia poniższych rozważań było orzeczenie Trybunału Konstytucyjnego z dnia 23 kwietnia 2008 r. ${ }^{1}$ dotyczące zgodności z Konstytucją art. 52 ust. 2 Kodeksu etyki lekarskiej².

Na wstępie należy podnieść, iż w przeszłości pojawiały się pewne obawy dotyczące tego, czy Trybunał Konstytucyjny przy aktualnym stanie prawnym, może podjąć się oceny kodeksu z uwagi na treść art. 2 ustawy z dnia 1 sierpnia 1997 r. o Trybunale Konstytucyjnym (Dz. U. Nr 102, poz. $643 \mathrm{z}$ późn. zm.). W dotychczasowej praktyce również okręgowe sądy lekarskie rozważały taką możliwość. Ale w świetle art. 3 ustawy o Trybunale Konstytucyjnym, który zezwala każdemu sądowi na przedstawienie Trybunałowi pytania prawnego, co do zgodności aktu normatywnego z Konstytucja, ratyfikowanymi umowami międzynarodowymi lub ustawa, jeżeli od odpowiedzi na pytanie prawne zależy rozstrzygnięcie sprawy toczącej się przed sądem, pojawiały się wątpliwości czy organy izb lekarskich są sądem w rozumieniu wyżej przytoczonego przepisu.

Przypomnieć w tym miejscu należy, że na gruncie poprzedniej Konstytucji, Trybunał wypowiadał się już w kwestii możliwości oceny Kodeksu etyki lekarskiej. Otóż w postanowieniu Trybunału Konstytucyjnego z dnia 7 października 1992 r. $^{3}$ zamieszczono tezę, że przedmiotem oceny

1 Wyrok TK z dnia 23 kwietnia 2008 r. sygn. akt SK 16/07, M.P. Nr 38, poz. 342.

2 Mowa tu o Kodeksie etyki lekarskiej, uchwalonym przez Krajowy Zjazd Lekarzy w 1991 r., a następnie zmienionym na III Krajowym Zjeździe Lekarzy w grudniu 1993 r. a wreszcie na Nadzwyczajnym VII Krajowym Zjeździe Lekarzy w dniu 20 września 2003 r. Dalej skrótowo nazywany KEL.

3 Orzeczenie Trybunału Konstytucyjnego z dnia 17 października 1992 r. sygn. akt U 1/92, opublikowane w: OTK 1992, nr 2, poz. 38. 
Trybunału Konstytucyjnego nie może być sama norma etyczna, a jedynie norma prawna, którą norma etyczna dookreśla. W rozpatrywanej sprawie uznano, że przedmiotem oceny Trybunału Konstytucyjnego w niniejszej sprawie były przepisy ustawy z dnia 17 maja 1989 r. o izbach lekarskich ${ }^{4}$ dookreślone przez normy Kodeksu etyki lekarskiej.

Z kolei w uchwale Trybunału Konstytucyjnego z dnia 17 marca 1993 r. (sygn. akt W 16/1992) sformułowano tezę, że art. $41 \mathrm{w}$ związku z art. 15 pkt 1 ustawy o izbach lekarskich nie ma zastosowania w zakresie, w jakim zachowanie się lekarza jest zgodne z nakazem lub zakazem albo upoważnieniem obowiązującej ustawy.

Natomiast w uzasadnieniu przywołanego już powyżej wyroku TK z dnia 23 kwietnia 2008 r., że możliwa jest kontrola normy ustawowej dookreślonej następnie przez treść konkretnego postanowienia aktu uchwalonego przez organ samorządu zawodowego. Stąd też uznano, że przedmiotem kontroli TK może być art. 52 ust. 2 KEL w związku z art. 15, 41 i 42 ustawy o izbach lekarskich. Wyjaśniono natomiast, że poza zakresem merytorycznej kontroli Trybunału pozostaje przyrzeczenie lekarskie. Argumentowano, że przysięga taka nie stanowi integralnego fragmentu KEL (brzmienie zostało bowiem ustalone odrębną uchwałą Krajowego Zjazdu Lekarzy bez wyraźnej podstawy prawnej), ponadto jedynie uogólnia normy zawarte w KEL. W tym samym orzeczeniu podkreślono, że w trybie skargi konstytucyjnej nie można badać zgodności kwestionowanych aktów normatywnych $\mathrm{z}$ umowami międzynarodowymi ${ }^{5}$.

4 Dz. U. Nr 30, poz. 158 z późn. zm.

5 Warto przy okazji niejako odnotować, że w tym samym wyroku (w uzasadnieniu) TK analizował zarzut naruszenie art. 17 ust. 1 Konstytucji. Podobnie jak w sprawie o sygn. akt P21/02 TK argumentował „Unormowanie art. 17 ust. 1 Konstytucji upoważnia samorządy zawodów zaufania publicznego do sprawowania pieczy nad należytym wykonywaniem tych zawodów. Ma być ona sprawowana - z wyraźnego nakazu ustrojodawcy - w granicach interesu publicznego i dla jego ochrony. Sformułowanie to, po pierwsze precyzuje cel i granice sprawowanej pieczy nad wykonywaniem zawodów. Cel ten to przestrzeganie właściwej jakości - w sensie merytorycznym i prawnym czynności składających się na wykonywanie zawodów. Po wtóre sformułowanie art. 17 ust. 1 wyznacza ramy i ukierunkowanie sprawowanej pieczy. Ramy te determinuje interes publiczny. [...] W analizowanym wypadku dotyczy to zarówno procesów stanowienia korporacyjnych norm deontologicznych, jak i ich wykładni oraz stosowania przez rzeczników odpowiedzialności zawodowej i sądy lekarskie. Organy samorządu zawodowego nie mogą nie uwzględniać treści art. 17 Konstytucji w toku wykonywania swoich ustawowych oraz statutowych kompetencji. Ustrojodawca, zezwalając na powierzenie organom samorządu zawodowego określonych zadań z zakresu administracji 
W pierwotnym brzmieniu KEL przepis, który formułował wspomnianą powyżej regułę, (art. $52 \mathrm{KEL}$ ) uzyskał następujące brzmienie:

„1. Lekarze powinni okazywać sobie wzajemny szacunek.

2. Lekarz nie powinien wypowiadać wobec chorego i jego otoczenia, a także wobec personelu asystującego lub publicznie, niekorzystnej oceny działalności zawodowej innego lekarza lub dyskredytować go w jakikolwiek sposób.

3. Wszelkie uwagi o dostrzeżonych błędach w postępowaniu innego lekarza powinien przede wszystkim przekazać zainteresowanemu lekarzowi. Poinformowanie organu izby lekarskiej o zauważonym naruszeniu zasad etycznych i niekompetencji zawodowej innego lekarza nie godzi w zasady solidarności zawodowej”.

Jak z powyższego wynika, w tej wersji tego przepisu zakazywano wypowiadania publicznie jakiejkolwiek niekorzystnej oceny działalności innego lekarza ${ }^{6}$. Dodatkowo piętnowano tu przypadki dyskredytowania innego lekarza.

Jak już wyżej wspomniano na Krajowym Zjeździe Lekarzy w 2003 r. dokonano istotnej zmiany KEL w tym także art. 52. I tak od 1 stycznia 2004 r. obowiązuje on w następującym brzmieniu: „Art. 52 1. Lekarze powinni okazywać sobie wzajemny szacunek. Szczególny szacunek i względy należą się lekarzom seniorom, a zwłaszcza byłym nauczycielom.

2. Lekarz powinien zachować szczególną ostrożność w formułowaniu opinii o działalności zawodowej innego lekarza, w szczególności nie powinien publicznie dyskredytować go w jakikolwiek sposób.

3. Lekarz wszelkie uwagi o dostrzeżonych błędach w postępowaniu innego lekarza powinien przekazać przede wszystkim temu lekarzowi. Jeżeli interwencja ta okaże się nieskuteczna albo dostrzeżony błąd lub naruszenie zasad etycznych powodują poważną szkodę, konieczne jest poinformowanie organu izby lekarskiej.

4. Poinformowanie organu izby lekarskiej o zauważonym naruszeniu zasad etycznych i niekompetencji zawodowej innego lekarza nie stanowi naruszenia zasad etyki.

publicznej i wprowadzając przymus przynależności do korporacji zawodowej, podnosi interes publiczny do rangi uzasadnienia i ostatecznego celu wyposażenia organów samorządu zawodowego w wymienione atrybuty. [...] Praktyka orzecznicza sądów lekarskich, polegająca na nadaniu przepisowi art. 52 ust. 2 KEL treści, która abstrahuje od nakazanego konstytucyjnie wartościowania, jest więc nieuzasadniona i wzmacnia zarzut naruszenia art. 54 ust. $1 \mathrm{w}$ zw. z art. 31 ust. 3 i art. 17 ust. 1 Konstytucji.

6 A. Gubiński, Kodeks etyki lekarskiej. Komentarz, Warszawa 1995, s. 182. 
5. Jeżeli popełniony błąd przez innego lekarza ma niekorzystny wpływ na stan zdrowia pacjenta należy podjąć działania dla odwrócenia jego skutków".

Najwięcej kontrowersji budzi jednak nadal ust. 2 art. 52 KEL. Jak z powyższego wynika, redakcja tego przepisu uległa ,złagodzeniu”. Mowa jest tu obecnie o konieczności zachowania szczególnej ostrożności w prezentowaniu sądów o innych członkach samorządu lekarskiego, ale już nie zabrania się wypowiadania się o innych kolegach. Ciagle natomiast przepis uniemożliwia dyskredytowania innych lekarzy. Wyjaśnić tu należy, iż pojęcie dyskredytowania należy rozumieć jako ,pomniejszanie czyjegoś autorytetu, czyjeś wartości, podważanie zaufania do kogoś lub czegoś ${ }^{7}$," albo jako skompromitowanie, zdyskwalifikowanie ${ }^{8}$ lub psucie komuś opinii. Za takie będzie zapewne uchodzić np. określenie „mieć drewniane ręce" użyte pod adresem innego lekarza ${ }^{9}$. Jeżeli takie sformułowanie użyte zostanie pod adresem lekarza, i to na dodatek operatora, to nie można mieć wątpliwości, iż ma charakter kompromitujący, dyskwalifikujący daną osobę jako fachowca, pomniejszający autorytet tej osoby, psujący komuś opinię. Wreszcie określenie ,publiczny” użyte w art. 52 KEL należy rozumieć w taki sposób, jaki temu pojęciu nadaje doktryna i judykatura na gruncie art. 216 k.k. Zatem przesłanka publicznego zdyskredytowania będzie spełniona wówczas, gdy „wypowiedź lub gest [...] może być rzeczywiście odebrany przez bliżej nieokreśloną liczbę osób"10.

Jak słusznie zauważył Trybunał Konstytucyjny w uzasadnieniu wyroku z 23 kwietnia 2008 r. zakresy znaczeniowe pojęcia „dyskredytować” i „krytykować” krzyżują się, ale nie pokrywają. Wskazano tam, że „krytyka w ścisłym znaczeniu tego słowa zakłada zawsze element analizy i oceny prawidłowości zachowania podmiotu krytykowanego, co z kolei umożliwia późniejszą, obiektywną ocenę jej prawidłowości i prawdziwości. Krytyka nie musi ponadto - przynajmniej z pojęciowego punktu widzenia - angażować uwagi osób trzecich, ale może ograniczać się do wymiany poglądów pomiędzy krytykującym a krytykowanym. Tymczasem istota

7 Słownikjęzyka polskiego, t. I, PWN, Warszawa 1978; Słownik wyrazów obcych, red. E. Sobol, Warszawa 2002, s. 258.

8 Słownik wyrazów obcych PWN, s. 167.

9 Tak przedstawiał się stan faktyczny w jednej ze spraw rozpatrywanych przez sądy lekarskie.

${ }_{10}$ Kodeks karny. Część szczególna, Komentarz do k.k. t. II, red. A. Zoll, Kraków 1998 , s. 668 . 
«dyskredytacji» [...] wiąże się ze skutkiem w postaci podważenia autorytetu, spowodowania ujemnej oceny postawy lub działalności określonej osoby w oczach innych. Wskazany negatywny skutek może być związany z obiektywną uzasadnioną albo nieuzasadnioną, albo w każdym razie weryfikowalną - oceną czyjegoś działania, albo ze sposobem traktowania danej osoby" ". Podsumowując ten wątek TK stwierdził, iż dyskredytacją będzie „krytyka dla samej krytyki” albo też reakcja nieadekwatna do wytkniętego błędu oraz zamierzonych, pozytywnych skutków społecznych ${ }^{12}$.

Warto tu odnotować, że podobne regulacje zawierały przedwojenne kodeksy etyki lekarskiej. I tak Zbiór zasad deontologii lekarskiej z 16 czerwca 1935 r. (zasada nr 18) stanowił, iż „Lekarzowi nie wolno wypowiadać wobec chorego lub jego otoczenia niekorzystnej oceny działalności zawodowej kolegi. Lekarzowi nie wolno zachowywać się w sposób, który może zdyskredytować poprzedniego lekarza”. Podobne zasady funkcjonowały w Kodeksie deontologii lekarsko-dentystycznej z dnia 1 maja 1948 r. (zasada nr 16). Z kolei w zasadzie nr 39 Zbioru zasad etyczno-deontologicznych polskiego lekarza z dnia 22 czerwca 1984 r. stanowiono: „Stosunki między lekarzami powinny opierać się na wzajemnym szacunku, lojalności i koleżeństwie, wynikających ze wspólnych celów i poszanowania trudu, wysiłku oraz odpowiedzialności, jaką lekarz ponosi w swojej działalności zawodowej”. W art. 40 przewidziano: „Lekarz nie powinien nigdy pochopnie oceniać działalności i umiejętności innego lekarza, a zwłaszcza opierać swych sądów na informacjach pochodzących od chorych i osób postronnych, gdyż informacje takie bywają często wynikiem nieporozumienia lub ubocznych względów”, a w art. 41 „Jeżeli zachodzi konieczność wydania opinii o pracy zawodowej innego lekarza, opinia taka może być wydana tylko na pisemne żądanie powołanych do tego władz, a także może być wyrażona w dyskusji naukowej lub na prośbę zainteresowanego lekarza. Opinia taka powinna być zgodna z zasadami etyczno-deontologicznymi i wydana w sposób bezstronny" oraz w art. 42 ,Lekarz powołany do wydania urzędowej opinii o postępowaniu innego lekarza powinien dokładnie zapoznać się ze wszystkimi materiałami i okolicznościami koniecznymi do wyjaśnienia sprawy, a swą opinię kształtować i wyrażać w sposób obiektywny i ostrożny. Opinie te

11 Wyrok Trybunału Konstytucyjnego z dnia 23 kwietnia 2008 r. (sygn. akt Sk 16/07), opublik. M.P. Nr 38, poz. 342.

12 Ibidem. 
powinny być $\mathrm{w}$ miarę możności opracowywane kolektywnie $\mathrm{z}$ udziałem właściwych specjalistów" ${ }^{\prime 3}$.

Z kolei podobne europejskie zbiory zasad deontologii lekarskiej zawierają inne rozwiązania. I tak w art. 28 Europejskich zasad etyki lekarskiej z 6 stycznia 1987 r. stanowi się: „obowiązujące lekarzy reguły koleżeństwa są ustanowione w interesie pacjentów i mają na celu zapobieżenie sytuacji, w której pacjenci staną się ofiarami nieuczciwej konkurencji między lekarzami”, a w art. 30 „Nie uchybia obowiązkowi koleżeństwa zgłoszenie przez lekarza właściwemu organowi zawodowemu faktu uchybienia regułom etyki lekarskiej i uprawnień zawodowych, o których lekarz się dowiedział", a w punkcie B6 załącznika do tego dokumentu „lekarz może uczestniczyć w reportażach publicznych w prasie, radiu i telewizji w zakresie, w jakim służą one informowaniu społeczeństwa w dziedzinie zdrowia. Lekarz, który uczestniczy w akcji informowania opinii publicznej o charakterze edukacyjnym lub bez względu na środek komunikacji, powinien powoływać się jedynie na potwierdzone dane, wykazywać ostrożność i troskę o konsekwencje swoich wypowiedzi do opinii publicznej"14.

Przy tej okazji warto podkreślić, że prawo do krytyki i wolność wypowiedzi gwarantują oprócz oczywiście Konstytucji Rzeczpospolitej z dnia 2 kwietnia 1997 r. (art. 54 - Dz. U. Nr 78, poz. 483 z późn. zm.) także akty rangi międzynarodowej. Wymienić tu należy chociażby Powszechną Deklarację Praw Człowieka, Międzynarodowy Pakt Praw Politycznych, Ekonomicznych i Socjalnych z 16 grudnia 1966 r. ratyfikowany przez Polskę 3 marca 1977 r. ${ }^{15}$ czy wreszcie Europejską Konwencję Praw Człowieka i Podstawowych Wolności z 4 listopada 1950 r. ratyfikowaną przez Polskę 15 grudnia 1992 r. $^{16}$

Przypomnieć w tym miejscu należy, że zgodnie z art. 54 ust. 1 Konstytucji „Każdemu zapewnia się wolność wyrażania swoich poglądów oraz pozyskiwania i rozpowszechniania informacji. Zarówno w doktrynie, jak w judykaturze panuje ugruntowany pogląd, iż przepis ten normuje trzy odrębne, choć powiązane ze sobą wolności, a mianowicie wolność rozpowszechniania informacji, wolność wyrażania poglądów oraz wolność po-

13 Patrz także uzasadnienie wyroku TK z 23 kwietnia 2008 r., sygn. akt Sk 16/07.

14 Patrz szerzej uzasadnienie wyroku Trybunału Konstytucyjnego z dnia 23 kwietnia $2008 \mathrm{r}$.

15 Dz. U. Nr 38, poz. 167 załącznik.

16 Dz. U. 1993, Nr 61, poz. 284 wraz z protokołami. 
zyskiwania informacji. Przy czym, jak wielokrotnie definiował to TK, „pogląd” ,[...] w rozumieniu art. 54 ust. 1 Konstytucji rozumie się nie tylko jako wyrażanie osobistych ocen co do faktów i zjawisk we wszystkich przejawach życia, ale również prezentowanie opinii, przypuszczeń, prognoz, ferowania ocen w sprawach kontrowersyjnych, a także informowanie o faktach tak rzeczywistych, jak i domniemanych"17. Przy czym - jak słusznie zauważył TK w cytowanym wyroku ,[...] swoboda wypowiedzi i prawo krytyki ma najszersze granice w sferze życia politycznego [...]. Zwłaszcza w tej sferze swoboda wypowiedzi jest jednym z fundamentów społeczeństwa demokratycznego, warunkiem jego rozwoju i samorealizacji jednostek. Wolność słowa obejmuje jednak i inne przejawy życia publicznego oraz sferę prywatną. Linia orzecznicza TK jest w tym punkcie zgodna z judykaturą ETPC, która podkreśla szczególne znaczenie, jakie wolność słowa ma dla kształtowania się postaw i opinii w sprawach budzących publiczne zainteresowanie i zatroskanie. Nie ulega zaś wątpliwości, że problematyka ochrony zdrowia i funkcjonowania służby zdrowia - zwłaszcza w zakresie, w jakim dotykają kwestii istotnych dla bezpieczeństwa pacjentów - należą do tego typu spraw"18.

Przypomnieć w tym miejscu należy, że zgodnie z kolei z treścią art. 5 ustawy z dnia 26 stycznia 1984 r. Prawo prasowe (Dz. U. Nr 5, poz. 24 z późn. zm.) „każdy obywatel, zgodnie z zasadą wolności słowa i prawem do krytyki, może udzielać informacji prasie. Nikt nie może być narażony na uszczerbek lub zarzut z powodu udzielania informacji prasie, jeżeli działał w granicach prawem dozwolonym". W doktrynie wskazuje się, iż krytyka jest ,publiczną oceną, opartą na konfrontacji jakiegoś stanu rzeczywistego z przyjętymi założeniami. Zadaniem krytyki jest wzbogacenie wiedzy i świadomości, a nie wymierzanie sprawiedliwości" ${ }^{\prime 19}$. Choć w języku polskim temu terminowi nadaje się jednoznacznie pejoratywne znaczenie, tym niemniej krytyka to analiza i ocena, która może przybierać postać dezaprobaty, ale też pochwały. Przy czym przedmiotem krytyki może być każdy przejaw życia społecznego ${ }^{20}$.

17 Patrz szerzej uzasadnienie wyroku Trybunału Konstytucyjnego z dnia 23 kwietnia 2008 r. i przytoczone tam orzecznictwo TK: wyrok TK z 5 maja 2004 r. sygn. akt P2/03, OTK ZU nr 5/A/2004, poz. 39; wyrok z 20 lutego 2007 r., sygn. akt P1/06, OTK $\mathrm{ZU}$ nr 2/A/2007, poz. 11.

18 Ibidem.

19 J. Sobczak, Ustawa prawo prasowe. Komentarz, Warszawa 1999, s. 90 i n.

20 Ibidem, s. 96. 
Doceniając rolę i zadania krytyki, zwłaszcza prasowej, ustawodawca za przestępstwo traktuje próby jej ograniczania i tłumienia, jak też zbierania materiałów krytycznych (tak art. 44 Prawa prasowego). Należy jednocześnie zaznaczyć, że wolność słowa i prawo do krytyki nie są wartościami nieograniczonymi. Zgodnie z art. 31 ust. 3 Konstytucji „Ograniczenia w zakresie korzystania z konstytucyjnych wolności i praw mogą być ustanawiane tylko w ustawie i tylko wtedy, gdy są konieczne w demokratycznym państwie dla jego bezpieczeństwa lub porządku publicznego, bądź dla ochrony środowiska, zdrowia i moralności publicznej, albo wolności i praw innych osób. Ograniczenia te nie mogą naruszać istoty wolności i praw”. Na tle tego przepisu TK wielokrotnie podkreślał, że „oceniając konstytucyjność regulacji ustanawiającej ograniczenie konstytucyjnej wolności lub prawa, należy rozważyć, czy spełnia ona kryteria formalne - tj. przesłankę ustawowej formy ograniczenia (przy czym wzgląd na fundamentalną rolę wolności słowa w demokratycznym państwie prawnym nakazuje szczególnie surowo kontrolować precyzję przepisów ustaw wprowadzających ograniczenia w korzystaniu z tej wolności) [...], a w razie pozytywnej odpowiedzi na to podstawowe pytanie przeprowadzić tzw. test proporcjonalności. Zgodnie z ustalonym na tle art. 31 ust. 2 Konstytucji orzecznictwie TK, zarzut braku proporcjonalności wymaga udzielenia odpowiedzi na trzy pytania dotyczące analizowanej normy: 1) czy jest ona w stanie doprowadzić do zamierzonych przez ustawodawcę skutków (przydatność normy); 2) czy jest ona niezbędna dla ochrony interesu publicznego, z którym jest powiązana (konieczność podjęcia przez ustawodawcę działania); 3) czy jej efekty pozostają w proporcji do nałożonych przez nią na obywatela ciężarów lub ograniczeń (proporcjonalność sensu stricto) ${ }^{, 21}$. Jednocześnie TK pokreślił, że ,[...] przekazanie upoważnienia do ingerencji w pewne konstytucyjne wolności osób wykonujących zawód zaufania publicznego samorządom zawodowym może być w określonych warunkach uzasadnione, a nawet uznane za zgodne z potrzebami należytego wykonywania zawodów reglamentowanych. Upoważnienie to nie może jednak mieć charakteru blankietowego. [...] Przystąpienie przez daną osobę - po spełnieniu ustawowo określonych warunków - do określonej korporacji zawodowej [...] jest równoznaczne z wolicjonalnym poddaniem się przez nią pieczy nad należytym wykonywaniem zawodu,

21 Patrz szerzej uzasadnienie wyroku Trybunału Konstytucyjnego z dnia 23 kwietnia 2008 r. 
a tym samym stanowi dobrowolne poddanie się unormowaniom wewnątrzkorporacyjnym" "22. Jednak w ocenie TK ,wystarczającym powodem uzasadniającym tę szczególną regulację [tj. możliwość ograniczenia wolności słowa - przyp. J.S.] nie może być ochrona godności i dobrego imienia innego (krytykowanego lekarza)"23. Choć jednocześnie TK przyznał, ze ,dopuszczenie w tych warunkach nieograniczonej krytyki, której zasadność miałaby być weryfikowana wyłącznie ex pos, w postępowaniu przed sądem, prowadziłoby do skutków społecznie szkodliwych zarówno w wymiarze powszechnym jak i indywidualnym"24.

Należy zatem z całą mocą podkreślić, iż granicami legalności krytyki jest rzetelność i zgodność z prawem i zasadami współżycia społecznego. Przy czym rzetelność należy rozumieć jako odpowiedzialny sposób relacji, zgodny z zasadami sztuki, nie stosujący niedozwolonych wybiegów ${ }^{25}$. Nie będzie zatem uchodzić za dopuszczalną krytykę postępowanie, które wypływa z chęci zniesławienia lub naruszenia godności osoby napiętnowanej $^{26}$. W doktrynie podkreśla się przy tym zasadnie, iż przyznanie prawa do krytyki nie oznacza zwolnienia z konieczności dochowania odpowiedniej formy krytyki. Krytyka winna zatem być rzetelna i zgodna z zasadami współżycia społecznego. Dlatego też niezasadnym wydaje się pogląd zakładający, iż krytyka niezgodna z prawdą pozostaje w ramach dozwolonych przez prawo. Podawanie bowiem nieprawdy, zwłaszcza w sposób świadomy i celowy, na pewno nie może uchodzić za postępowanie zgodne z zasadami współżycia społecznego, a zarazem będące rzetelnym. Granice dozwolonej krytyki prasowej wyznaczają: konstytucja, prawo prasowe, normy prawa cywilnego, karnego, a wreszcie zasady współżycia społecznego ${ }^{27}$. W ramach tak ukształtowanego katalogu wymienić należy reguły deontologii zawodowej zawarte w Kodeksie etyki lekarskiej. Dla potwierdzenia tej tezy warto też przywołać tu poglądy judykatury. W wy-

22 Patrz szerzej uzasadnienie wyroku Trybunału Konstytucyjnego z dnia 23 kwietnia 2008 r.

23 Ibidem.

24 Ibidem.

25 J. Sobczak, op. cit., s. 96.

26 Zob. wyrok Sądu Apelacyjnego w Krakowie z dnia 12 stycznia 1994 r., I ACr 314/93; z dnia 13 maja 1997 r. I ACa 185/97 oraz z 19 listopada 1996 r., I ACr 115/96, wszystkie orzeczenia zamieszczono w: B. Gawlik, Dobra osobiste, Kraków 1998.

27 Tak J. Sobczak, op. cit., s. 134; I. Dobosz, Odpowiedzialność karna za przestępstwa prasowe, RPEiS 1985, nr 3, s. 45-46. 
roku Sądu Najwyższego z 3.12.1986 r. ${ }^{28}$ wyrażono stanowisko, iż ,,[...] obszar dopuszczalnej krytyki prasowej nie może wykraczać poza granice zgodnego z prawdą relacjonowania faktów. Spełnienie nakreślonych $\mathrm{w}$ art 41 prawa prasowego przesłanek powoduje uchylenie bezprawności takiego działania. Brak bezprawności czynu z uwagi na dopuszczalne wyrażenie negatywnych ocen działalności publicznej czy zawodowej nie dotyczy sytuacji, gdy owa negatywna opinia przekracza powszechnie dopuszczalne granice,"29.

Zważywszy na powyższe należy podkreślić, że w obecnym kształcie art. $52 \mathrm{KEL}$ piętnuje tylko publiczne dyskredytowanie innego lekarza, a więc pomniejszanie, podważanie czyjegoś autorytetu, kompromitowanie kolegi z korporacji zawodowej. Przy czym, co należy z całą mocą podkreślić, przewiduje jednocześnie stosowny tryb zmierzający do wykrycia i ukarania błędów w postępowaniu innego lekarza. Stąd też obowiązek poinformowania organów izby lekarskiej. Analogicznie, mimo istnienia art. 54 Konstytucji, kodeks karny penalizuje zniesławienie i znieważenie.

W konsekwencji Trybunał Konstytucyjny w wielokrotnie tu cytowanym wyroku z dnia 23 kwietnia 2008 r. podkreślił, iż „Trybunał uznaje potrzebę istnienia pewnych ograniczeń wolności słowa i prawa do krytyki w relacjach pomiędzy lekarzami, ze względu na konieczność ochrony zaufania pacjentów do służby zdrowia, niezbędnego do prawidłowego funkcjonowania tej profesji jako całości, specyfikę relacji pacjent - lekarz, opartej na zaufaniu pacjenta do lekarza, wreszcie specyfikę decyzji diagnostycznych i terapeutycznych, podejmowanych z reguły w warunkach braku pełnego rozeznania wszelkich uwarunkowań danego przypadku. Uzgodnieniu tych konkurujących ze sobą wartość służy procedura informacyjna usytuowana w art. 52 ust. 3 KEL. Nie znaczy to jednak, że opisany tam mechanizm zawsze będzie wystarczający i dostatecznie skuteczny, aby zapewnić ochronę wartości podstawowej w analizowanym zakresie - tj. zdrowia i życia pacjentów. In casu, w granicach podyktowanych ochroną tej wartości oraz - co oczywiste - prawdziwością formułowanych twierdzeń, może zaistnieć konieczność wystąpienia z publiczną krytyką innego lekarza. Interpretacja zakwestionowanego art. 52 ust. 2 KEL

28 Orzeczenie Sądu Najwyższego, sygn. akt I CR 378/86, opublik. w OSNC 1988/4/47.

29 Por. G. Rejman, Odpowiedzialność w prawie prasowym, „Palestra” 1984, nr 3-4; J. Sobczak, Prawo prasowe w działalności prasy lokalnej, Poznań 1993; tenże, Prawo prasowe. Komentarz, Warszawa-Poznań 1992. 
zgodna z aprobowanym konstytucyjnie systemem wartości nie może zatem zmierzać w kierunku uznania całkowitej niedopuszczalności publicznej krytyki lekarza przez innego lekarza i zwolnienia sądów lekarskich z przeprowadzania dowodu prawdy przy dokonywaniu ocen wartościujących konkurujące ze sobą w konkretnym wypadku interesy"30.

Warto w tym miejscu odnotować, że w innych samorządach zawodowych zasady krytyki dokonywanej pomiędzy członkami samorządu zostały uregulowane w różny sposób. I tak w Kodeksie etyki adwokackiej ${ }^{31}$ stanowi się jedynie ogólnie, iż adwokat powinien przestrzegać w stosunku do kolegów zasad uprzejmości, lojalności i koleżeństwa, a nadto, iż adwokat zobowiązany jest do najwyższej lojalności wobec kolegów współpracujących w ramach kancelarii lub spółki i powstrzymywania się od jakichkolwiek działań naruszających taką lojalność również po zakończeniu współpracy. Zgodnie z § 39 tego dokumentu w razie sporu między adwokatami, należy wyczerpać przede wszystkim możliwości jego polubownego rozstrzygnięcia lub skorzystać z pośrednictwa właściwych władz adwokatury. W przypadku kolizji między zasadami koleżeństwa a uzasadnionym interesem klienta, należy dać pierwszeństwo interesom klienta.

Z kolei w art. 38 Kodeksu etyki radcy prawnego stanowi się już wyraźnie, iż ,niedopuszczalne jest wypowiadanie przez radcę prawnego wobec osób trzecich negatywnej opinii o pracy zawodowej innego radcy prawnego. Radca prawny, do którego zwrócono się o wydanie opinii o innym radcy prawnym, obowiązany jest wysłuchać opiniowanego radcę prawnego, a przy sporządzaniu opinii opierać się na dokumentach, znanych mu faktach oraz zachować obiektywizm i rzeczowość. Wydanie negatywnej opinii o radcy prawnym, także co do jego pracy zawodowej, jest dopuszczalne, jeżeli opinia taka jest oparta na faktach, a potrzeba albo obowiązek jej wydania wynikają z zadań lub uprawnień służbowych bądź samorządowych",32.

W Kodeksie etyki notariuszy ${ }^{33} \mathrm{w} \S 25$ zapisano, iż notariusz powinien kierować się zasadą lojalności, życzliwości i szacunku w stosunku do in-

30 Ibidem.

31 Zbiór zasad etyki adwokackiej i godności zawodu uchwalony przez Naczelną Radę Adwokacką dnia 10 października 1998 r., uchwała nr 2/XVIII/98.

32 Załącznik do uchwały nr 5 VII Krajowego Zjazdu Radców Prawnych z dnia 11 listopada $2007 \mathrm{r}$.

33 Uchwała nr 19 Krajowej Rady Notarialnej z dnia 12 grudnia 1997 r. Kodeks etyki zawodowej notariusza. 
nych notariuszy, zachowując wszakże prawo do oceny ich pracy, a zarazem wystrzegając się jakichkolwiek form nieuczciwej konkurencji zawodowej. Z kolei zgodnie z § 28 informacji o notariuszach udzielać mogą środkom przekazu tylko organy samorządu notarialnego. Notariusz winien jest wcześniej informować Radę Izby Notarialnej o swym udziale bądź współpracy z jakimkolwiek środkiem przekazu publicznego. Natomiast w $\S 31$ przewidziano zakaz krytykowania wobec klientów czynności dokonanych przez innych notariuszy. Gdy istnieje zatarg między notariuszami, mogą oni wystąpić w sporze sądowym po uprzednim przeprowadzeniu postępowania wyjaśniającego przez Radę Izby Notarialnej (§ 33 Kodeksu etyki notariuszy).

W Kodeksie etyki pielęgniarek i położnych podkreślono, że pielęgniarka nie powinna dyskredytować postępowania innych współpracowników zespołu terapeutycznego, zwłaszcza w obecności osób trzecich. $\mathrm{Z}$ kolei w regułach 4.13 . Kodeksu etyki architektów ${ }^{34}$ przewiduje się, iż członkowie tego samorządu zawodowego nie krytykują złośliwie lub nieuczciwie ani nie dyskredytują w ten sposób pracy innych architektów.

Wreszcie wracając na grunt Kodeksu etyki lekarskiej, trzeba odwołać się raz jeszcze do przywoływanego już orzeczenia Trybunału Konstytucyjnego z dnia 23 kwietnia 2008 r. (sygn. akt SK 16/07). TK przesądził tu, że art. 52 KEL w zakresie, w jakim zakazuje zgodnych z prawdą i uzasadnionych ochroną interesu publicznego wypowiedzi publicznych na temat działalności zawodowej innego lekarza jest niezgodny $\mathrm{z}$ art. 54 ust. 1 w zw. z art. 31 ust. 3 i art. 17 ust. 1 Konstytucji oraz nie jest niezgodny z art. 63 ustawy zasadniczej. Zatem - co należy wyraźnie podkreślić - stwierdzono, że norma art. 52 KEL w zw. z art. $15^{35}$ i $41^{36}$ ustawy o izbach lekarskich jest obarczona wadliwością konstytucyjną tylko w pewnej części i to przy określonym sposobie rozumienia. Stąd też-zdaniem Trybunału - nie ma konieczności zmiany ani aktów normatywnych,

34 Kodeks etyki zawodowej architektów, załącznik do uchwały 01 III Sprawozdawczego Krajowego Zjazdu Izby Architektów z dnia 18 czerwca 2005 r.

35 Art. 15 ustawy o izbach lekarskich „Członkowie samorządu lekarzy obowiązani są przestrzegać:

1) zasad etyki i deontologii oraz innych przepisów związanych z wykonywaniem zawodu lekarza,

2) uchwał władz i organów samorządu lekarzy".

36 Art. 41. Członkowie samorządu lekarzy podlegają odpowiedzialności zawodowej przed sądami lekarskimi za postępowanie sprzeczne z zasadami etyki i deontologii zawodowej oraz za naruszenie przepisów o wykonywaniu zawodu lekarza. 
ani Kodeksu etyki lekarskiej. Jak stwierdził TK „osiagnnięcie pożądanego rezultatu może nastąpić przez zmianę wykładni art. 52 ust. 2 KEL, dokonywanej w orzecznictwie sądów lekarskich, [...] tj. uznania, że pojęcie «dyskredytowanie» oznacza publiczną wypowiedź niezgodną z prawdą lub bez związku z ochroną interesu publicznego, wyłącznie lub przede wszystkim w celu podważenia autorytetu (zaufania do) innego lekarza"37.

\section{Summary}

The subject of this paper is the analysis of regulations approved by the medical profession self-governing bodies, which introduce the principle of professional loyalty. The reason undertaking subject was provided by the April 23, 2008 decision of the Polish Constitutional Tribunal on conformity of Art. 52 of the Code of Medical Ethics with the Polish Constitution.

37 Patrz wyrok TK z 23 kwietnia 2008 r. 
